\title{
Calcium-Enriched Nanofibrillated Cellulose/Poloxamer in-situ Forming Hydrogel Scaffolds as a Controlled Delivery System of Raloxifene $\mathrm{HCl}$ for Bone Engineering [Retraction]
}

\begin{abstract}
Kamel R, El-Wakil NA, Elkasabgy NA. Int J Nanomedicine. 2021;16:6807-6824.

The Editor and Publisher of the International Journal of Nanomedicine wish to retract the published article. Concerns were raised regarding alleged image manipulation relating to Figure 8. The authors immediately responded to our queries and confirmed that the image had indeed been manipulated and informed us the work shown in Figure 8 came from a contracted researcher and the authors used the provided images as received.
\end{abstract}

The authors were able to provide the original images for Figure 8 but they could not be used as a replacement and both the Editor and authors agreed to retract the article.

Our decision-making was informed by our policy on publishing ethics and integrity and the COPE guidelines on retraction.

The retracted article will remain online to maintain the scholarly record, but it will be digitally watermarked on each page as "Retracted".

\section{Publish your work in this journal}

The International Journal of Nanomedicine is an international, peerreviewed journal focusing on the application of nanotechnology in diagnostics, therapeutics, and drug delivery systems throughout the biomedical field. This journal is indexed on PubMed Central, MedLine, CAS, SciSearch ${ }^{\mathbb{}}$, Current Contents ${ }^{\mathbb{R}} /$ Clinical Medicine,
Journal Citation Reports/Science Edition, EMBase, Scopus and the Elsevier Bibliographic databases. The manuscript management system is completely online and includes a very quick and fair peer-review system, which is all easy to use. Visit http://www.dovepress.com/ testimonials.php to read real quotes from published authors. 